\author{
Paulina Sztabińska-Kałowska \\ - https://orcid.org/0000-0003-4617-7947 \\ Institute of Art History, University of Łódź \\ paulina.sztabinska@uni.lodz.pl
}

\title{
A DISCOURSE WITH ARCHITECTURE IN THE WORKS OF KRZYSZTOF WODICZKO
}

\begin{abstract}
The works of Krzysztof Wodiczko can be divided into three groups. The first one consists of different types of vehicles. The second group of Wodiczko's works, according to Stach Szabłowski, are "the designs of technological prostheses for socially <<disabled $>$ people - refugees, migrants, the homeless". The third and most well-known group are public projections, which consist in projecting images onto different famous buildings (first static images and, since 1996, moving ones, and images combined with sound), aimed at attracting the audience's attention to cultural, social and political issues important to the dwellers of the given place. In the article, the author focuses on describing the last of the mentioned groups, pointing out that the artist's projections on the one hand relate to real, current problems of the dwellers of a given place and, on the other hand, as they are created with the thought of specific buildings in mind, they enter a discourse with architecture which is commonly perceived as universal, timeless and far from what is happening now.
\end{abstract}

Keywords: discourse, architecture, public projections, Krzysztof Wodiczko

The works of Krzysztof Wodiczko can be divided into three groups. The first one consists of different types of vehicles. Some of them have a metaphorical meaning (e.g. Vehicles from the years 1971-1973), while other ones serve specific purposes (e.g. Homeless Vehicle from the years 1988-1989) or involve political and social engagement (vehicles used in War Veteran Projections created since 2008). According to Stach Szabłowski, the second group of Wodiczko's works are "the designs of technological prostheses for socially <<disabled〉> people - refugees, migrants, the homeless"1. The third and most well-known group are public projections which consist in projecting images onto different 
famous buildings (first static images and, since 1996, moving ones, and images combined with sound), aimed at attracting the audience's attention to cultural, social and political issues important to the dwellers of the given place. The last of the groups is especially interesting to me, as, on the one hand, the artist's projections refer to real current problems of the dwellers of a given place and, on the other hand, as they are created with the thought of specific buildings in mind, they enter a discourse with architecture which is commonly perceived as universal, timeless and far from what is happening now.

The term "projection", as Wodiczko emphasized it, "comes from the Latin proiectio (taking out), pro- meaning forward. In a broader sense, <<projection〉> means an action, a process, state, technique, an effect of showing something or outlining something, of emphasizing something against the surface, against a background or against the surroundings; it refers to something becoming visible, appearing or showing. Projections as pro-jections suggest movement toward something new. At the same time, the term is also kind of connected with e-jection (throwing something out ahead of oneself and out of oneself) and it is also possibly connected with the re-jection of something or someone"2. However, which was pointed out by the artist, the place where a projection is made is very important for it to make the right impression. For Wodiczko, buildings and monuments situated in city centres, known very well by both the dwellers and tourists, have been ideal for the purpose. Their recognisability and rank served to attract viewers' attention, and make the message conveyed by the projections more noticeable. Wodiczko wrote that "The city is a monumental stage for things to $<<$ go on $>>$ because it perpetuates both a spatial relationship between its inhabitants and its symbolic structures, and a psycho-social relationship among its dwellers". ${ }^{3}$

However, the idea of making projections formed gradually. Works from the years 1976-1977 can be regarded as their genesis. Back then, Wodiczko created the works entitled Show and Conversation About Line and References. In the former, the artist placed three canvases presenting a vertical, horizontal and diagonal line on one of the walls of Akumulatory 2 Gallery in Poznan. Images from transparencies were projected onto another wall, under drawings of lines replicating those painted on the canvases, connecting individual lines to images of works of architecture, art and political press photography. As for

1 S. Szabłowski, Dobry artysta, „dwutygodnik.com” 2015, Vol. 166, No. 8, www.dwutygodnik. com/artykul/6064-dobry-artysta.html (07.11.2020)

2 K. Wodiczko, Monument, Parrhesia, Projection [in:] Krzysztof Wodiczko. Art of the public domain, ed. B. Czubak, Państwowa Galeria Sztuki w Sopocie, Fundacja Profile w Warszawie, Sopot-Warszawa 2011, p. 168.

3 K. Wodiczko, Designing for the City of Strangers [1997], [in:] idem, Critical Vehicles. Writings, Projects, Interviews, The MIT Press, Cambridge - Massachusetts - London 1999, p. 4. 
the other work, References (1977, Foksal PSP Gallery), a transparency projection was taking place directly on three canvases with a horizontal, vertical and diagonal line. ${ }^{4}$ For Wodiczko, the next step in developing works in which he used images displayed by a projector were Guidelines from the year 1978, exhibited in Hal Bromm Gallery in New York. In these works, the artist gave up lines in favour of "tilting or linearly arranging images" which were projected directly onto the gallery walls in a deformed form. ${ }^{5}$ Giving up canvas in favour of a white wall made the artist aware that it is not a "flat, neutral surface". ${ }^{6}$ There are sometimes different cracks, doors, radiators and other, more or less obvious and predictable elements. It appeared, as the artist wrote, that "<guidelines> are also present in the architecture of the interior [...], in its geometry". ${ }^{7}$ That is why during an exhibition in Halifax, in Eye Level Gallery (1979), the artist moved part of an installation, which consisted in displaying different images on a wall, from the first to the ground floor. Next, Wodiczko made some projection attempts at a subway station in Toronto. However, the first truly public projection took place on the neoclassical facade of the Faculty of Architecture building in Halifax in 1979. The artist projected images of a hand palm in different positions, expressing various gestures, onto sculptures placed on the platforms on both sides of the entrance to the representative building. As he said later, "that was the beginning of animating buildings, showing <the body of architecture>, a bit according to the rule described by Winckelmann in the neoclassical theory of architecture seen as a metaphor of the body. [...] Looking at a building, we embody its architecture; in connection with a disciplining body of a building, we feel disciplined ourselves". ${ }^{8}$

Wodiczko's projections, as I have already mentioned, are always organized at places of importance for the given city - representative buildings or important monuments. This gives the projections a higher public rank and makes the problems which the artist tackles more visible. The power of official and representative architecture, through contrast with people talking about themselves and the topics of a projection, makes the words uttered by the dwellers who are normally marginalized even more telling. It reveals social contrasts and provokes reflection. As Bożena Czubak wrote, Wodiczko "vested the monuments, frozen in their celebration of the past, with new roles and new meanings"',

4 Description after: Lata siedemdziesiate [in:] Krzysztof Wodiczko. Na rzecz domeny publicznej, ed. B. Czubak, Muzeum Sztuki w Łodzi, Łódź 2015, pp. 111-113

K. Wodiczko, ibidem, p. 111.

Ibidem, p. 112.

Ibidem, p. 112.

Ibidem, pp. 112-113.

B. Czubak, Art of the public domain, [in:] Krzysztof Wodiczko. Art of the public domain, op. cit., p. 008. 
simultaneously disclosing their "disciplining function". ${ }^{10}$ The artist himself added: "The history of the victors must be confronted and interrupted by the memory of the nameless or the tradition of the vanquished". ${ }^{11}$

From that moment on, architecture has become the basis for projections, for their construction, a kind of canvas and, at the same time, a point of reference for Wodiczko. The artist entered a discourse with architecture. Each of his transparency projections and shows has been prepared with the thought of a specific building in mind. On the one hand, the artist's creations were to fit the existing architectural divisions. On the other hand, their role was to lead to a change in their perception. In a text written in 1983, Wodiczko pointed out the myth-creating role of architecture, both as an institutional "site of the discourse of power" and a "metainstitutional, spatial medium for the continuous and simultaneous symbolic reproduction of both the general myth of power and the individual desire for power". ${ }^{12}$ "For these purposes - he wrote - the building is <sculptured> to operate as an aesthetic structure, thus assisting in the process of inspiring and symbolically concertizing (reflecting) our mental projections of power". ${ }^{13}$ From such a perspective, on the one hand, architecture is a medium thanks to which certain content is delivered to us. On the other hand, it often becomes a tool of broadly understood power, both on a state (public utility buildings) and corporate (company and industrial concern buildings) level. In this way, Wodiczko wants to show that a human being is constantly and unconsciously subjected to manipulation. ${ }^{14}$ Referring to Stéphane Mosès's and Walter Benjamin's concept, the artist wrote: "The history of the victors - the official presence of the official past, constitutes the official city". ${ }^{15}$ Passing buildings by, we do not always pay attention to their appearance, structure and aura. As intended by the artist, "the method of projection" is to stop this "ideological $<<$ ritual >>" and restore public attention, allowing for the "concentration on the building and its architecture". ${ }^{16}$ The artist's projections aim at revealing what is hidden. "The myth - as he wrote - must be visually concretized and unmasked. (...) Only a physical, public projection of the myth on the physical body of myth

10 Ibidem, p. 007.

11 K. Wodiczko, Designing for the City of Strangers [1997], [in:] idem, Critical Vehicles. Writings, Projects, Interviews, The MIT Press, Cambridge - Massachusetts - London 1999, p. 4.

12 K. Wodiczko, Public Projection (1983), [in:] Krzysztof Wodiczko. Art of the public domain, op. cit., p. 158.

13 Ibidem.

14 Ibidem.

15 K. Wodiczko, Designing for the City of Strangers [1997], [in:] idem, Critical Vehicles. Writings, Projects, Interviews, The MIT Press, Cambridge - Massachusetts - London 1999, p. 4.

16 K. Wodiczko, Selected Projections (1983), [in:] Krzysztof Wodiczko. Art of the public domain, op. cit, p. 158. 
(projection of myth on myth) can successfully demythify the myth". ${ }^{17}$ So, the role of projections is to reveal certain mechanisms of power, make the viewer aware of them and provoke them to take action.

At the beginning, Wodiczko's works consisted in projecting transparencies showing enlarged human body parts - hand palms, legs and faces - onto representative buildings. His most famous works were related to violence, homelessness and AIDS. However, the early works that he started his public projections with were directed toward the world of art. The projection from the year 1982 on the Art Gallery of New South Wales in Sydney referred to the ambiguity characteristic for the functioning of the institution of art which, on the one hand, uses a discourse of openness but, on the other hand, authoritarian content implicated in state systems. The main motif of this projection were subsequently shown images of closed and open hand palms, displayed on the walls of the building's side wings, while ears were projected onto the side walls of the portico that constituted the main entrance to the gallery building. A view of an angrily frown eyebrow could be seen on the pediment. The work was intended as Wodiczko's sign of support for Australian artists demanding legal regulations concerning their participation in Biennale. ${ }^{18}$ Other works in which the artist tackled the problem of the museum institution were, among others, the projections on the Museum of Natural History in Regina, Saskatchewan, Canada (1983) or the Seattle Art Museum in 1984. The former concerned criticism of the way works of art produced in cultures other than those conforming with the European and Northern American tradition are collected. The latter was a critical view of museum institutions and their tendency to store most of their collections in warehouses, which makes it impossible for visitors to get in touch with them. ${ }^{19}$ Czubak wrote: "The projections, carried out using colour transparencies, with architecture becoming a screen for critical interventions in city space, combined a tradition of Situationist disturbance of peace with the precision of modern presentation techniques and have often been included in official cultural events, festivals, art biennials, New Year celebrations, used as yet another element of the urban spectacle". ${ }^{20}$

In the 1990s, along with the development of new technologies, Wodiczko replaced traditional transparencies with projections using multimedia projectors. Not only did they allow him to project image onto buildings, but also include motion and sound (by using additional speakers). Commenting on his

17 Ibidem.

18 Description after: Selected Protections 1980-2010, [in:] Krzysztof Wodiczko. Art of the public domain, op. cit. p. 035

19 See Krzysztof Wodiczko. Art of the public domain, op. cit, p. 040 and 051.

20 B. Czubak, Krzysztof Wodiczko. Art of the public domain, op. cit., p. 016. 
works from that time, the artist then wrote: "I was trying to combine the coupled dimensions - equipment and monument, design and projection, performativity and narrativity, image and sound". ${ }^{21}$

The first such work was the two-hour Public Projection on the Old City Hall Tower in Cracow on August 2nd-4th 1996. Beata Nowacka-Kardzis pointed out that Wodiczko "wanted to see Cracow the way that its dwellers do not want to see it". ${ }^{22}$ The aim of the artist was to give the floor to people who are usually marginalized in society and invisible in city life - the homeless, drug addicts, the disabled, ill and victims of violence who unwillingly admit what is happening at their homes. Wodiczko wanted to reveal their presence and show they are part of the given society. The choice of the place for the projection the Old City Hall Tower - was not incidental, either. It is a building located on the Main Market Square, very characteristic for the city, passed by tens of thousands of people each day - dwellers, students and tourists - which was to become "a stand for people who have so far remained unnoticed in public city space". ${ }^{23}$

The recordings of stories told by the people and projected onto the tower included both their voices and recordings of the gestures they made. In order to intensify the impression they made and give their statements a deeper context, each of the storytellers was holding a chosen object in their hands. Thanks to this, not only was the tower speaking, but it also had a physical aspect - it was moving. Nowacka-Kardzis also pointed out that "anyone who watched the projection was able to identify themselves with the tower devoid of a face. The tower could have been me, my acquaintance, neighbour or brother. It could have been you". ${ }^{24}$ In a way, it became a performer acting in public space.

Wodiczko prepared most of his later projections based on analogical rules. Another famous work was a projection on the wall of the Atomic Bomb Dome by the Motoyasu River in Hiroshima, displayed during two nights on August 7th and 8th, 1999. It included statements made by the projection participants, who were direct or indirect victims of radiation caused by the nuclear attack on Hiroshima on August 6th 1945, recorded on tape and played cyclically. The recorded voices were accompanied by the image of gesticulating hands. As the project curator wrote, the main idea was to "create an illusion that it is the Dome that is speaking to the audience gathered and that the participants

21 K. Wodiczko, Przyrzady, projekcje, pomniki, [w:] Publiczna przestrzeń dla sztuki?, ed. M. A. Potocka, Bunkier Sztuki, Kraków 2002, p. 46.

22 B. Nowacka-Kardzis, Wodiczko. Projekcje publiczne 1996-2004, Bunkier Sztuki, Kraków 2005, p. 17.

23 Ibidem, p. 17.

24 Ibidem, p. 18. 
identify with it [...] The Atomic Bomb Dome became a testimony for post-war Hiroshima and a witness of its present history, not a monument of the past". ${ }^{25}$

Yet more performative character of Wodiczko's works was revealed in a projection from the year 2001, which took place on February 23rd-24th at the building of El Centro Cultural in Tijuana, Mexico. The building is part of a larger complex consisting of numerous places serving cultural purposes, such as a theatre, museums, galleries, bookshops, educational rooms and restaurants. It has a shape of an enormous sphere designed by IMAX, resembling, from Wodiczko's perspective, "the tomb which Boullée designed for Newton, or a gigantic pre-Columbian construction". ${ }^{26}$ For the first time, the artist did not use recorded material and the whole projection was live, in real time. During the projection, six women representing different generations talked about their personal experiences - sexual harassment, mobbing at work, trouble with the police. The face of each of the women telling their stories was projected onto the building. Commenting on his work, Wodiczko wrote: "Women taking part in a live projection were able to bring the outer layer of the building to life, transforming its faceless, dumb mass into a manifestation of their presence". ${ }^{27}$ Further on, he emphasized that "this performative act of speech, which was a transition from a testimony to a transformative public action, became an important stage of shaping their ability to intervene in real life". 28

A projection onto the building of the Central Library in St. Louis, which took place on April 16-18th 2004, had yet a different character. There, Wodiczko tackled the problem of violence against children. The artist recorded the words of both violence perpetrators and victims. The projection consisted of ca. 20-minute long, previously recorded statements, which were played in their entirety or partly, a few times each evening, as well as live statements. Each of the projection participants could approach a microphone placed at the foot of the stairs leading to the Library and "talk to it", asking questions or telling their own story. ${ }^{29}$ The voice emitted from the speakers was accompanied by an image of gesticulating hands (belonging to the artist's friends or local actors ${ }^{30}$ ) projected onto the building synchronically with the previously recorded statements made by violence perpetrators.

25 T. Echizen, Wodiczko. Projekcje publiczne 1996-2004, Bunkier Sztuki, Kraków 2005, p. 62.

26 K. Wodiczko, Wodiczko. Projekcje..., op. cit., p. 82.

27 Ibidem.

28 Ibidem.

29 B. Hansman, Wodiczko. Projekcje publiczne ..., op. cit., p. 106.

30 It was an exceptional situation which resulted from the fact that in prison, where the statements made by the violence perpetrators were recorded, the artist was not allowed to record image, but just sound. 
A combination of the artist's interest in vehicles and projections resulted in War Veteran Projections. Such an artistic event was held for the first time in Denver, on the walls of the Performing Art Center and Armor buildings, in August 2008, during the Democratic Party's National Convention. Wodiczko used a military Humvee vehicle, which had been demilitarized and adapted for the purposes of the projection, equipped with a multimedia projector and speakers instead of a missile launcher. During the projection, conversations between the artist and American war veterans were presented. They mainly referred to the difficult life situation of the soldiers after their return to the fatherland and their life outside the army. ${ }^{31}$ Another version of this project, carried out in cooperation with British veterans, was shown in September 2009 in Liverpool. The War Veteran Projection shown on November 9-10th 2010 in Warsaw was still a bit different. This time, the artist utilized a Honker Skorpion-3 vehicle, used by Polish soldiers in Iraq. A combat module at the back of the vehicle had been replaced with a specifically designed projection stand including projectors and speakers. The vehicle was driven around Warsaw, stopping at a few locations chosen by the artist: the Krasinski Palace, the Grand Theatre-National Opera, a building of Warsaw University of Technology and a chosen tenement house close to Krakowskie Przedmieście, where words from statements made by Polish veterans of the wars in Iraq and Afghanistan, and their family members, emitted from the speakers, were displayed. The statements concerned traumatic war experiences and problems with returning to a normal life. ${ }^{32}$ The voice recording was replicated through a graphic recording in the form of white inscriptions. The words projected against the buildings would appear and disappear. As Kobylt wrote: "each of the statements included a key phrase in the form of the most shocking thread, whose graphic form was fired from the combat module of the vehicle after the end of the speech, in the rhythm of weapon fire sounds". ${ }^{33}$ At the same time, the veterans' faces were not revealed and they remained hidden behind their traumatic stories and experiences.

All Wodiczko's projections are preceded by a "community interview". $\mathrm{He}$ contacts different people living in the given area, talks about their problems and dilemmas, and listens to stories from their lives. He also collects information on the overall situation of the given community. In the case of War Veteran Projections, the creation of the projection was preceded by meetings with the project participants over a period of seven months. As Czubak wrote, "the artist's

31 See J. Kobyłt, Radykalna utopia - o krytyce społecznej Krzysztofa Wodiczki, https://archiwumobieg.u-jazdowski.pl/recenzje/9987 (17.06.2021)

32 A description according to: http://artmuseum.pl/pl/filmoteka/praca/wodiczko-krzysztofprojekcja-weteranow-wojennych-warszawa

33 J. Kobylt, Radykalna utopia, op. cit. 
working method involves initiating therapeutic meetings and workshops that let him activate veteran circles and involve them in carrying out the project". ${ }^{34}$ The Polish art historian also pointed out the performative character of this project, identifying it as "the active participation of the people who co-create the projection and the initiation of the viewers' reactions as users of public space". ${ }^{35}$

The problem of the performativity of Wodiczko's works has been raised many times and in different contexts, both in texts about his artistic activity written by critics and statements made by the artist himself. The aspects that have most often been focused on are the processual character of Wodiczko's works that are stretched in time and the co-participation of other people, engaged in both creating the work and its reception. In his book entitled Site-Specific Art Performance, Place and Documentation, while referring to Henri Lefebvre's concept $^{36}$, Nick Kaye talks about Wodiczko's works in the context of performing the city. The author noticed that the Polish artist's projects are part of the "experience of the city" by creating a "counter-image" and "counter-monument" that co-participate in the way we see urban space. ${ }^{37}$

When describing public projections, Wodiczko himself emphasized many times that "performative animations of city monuments are based on a collaboration with the inhabitants". ${ }^{38}$ Such a perspective makes it possible for us to understand the artist's projections as specific performances ${ }^{39}$ taking place on the facades of the buildings that he chooses, where architecture enters into a discourse with the viewer and surroundings.

\section{BIBLIOGRAPHY:}

Czubak Bożena, eds. (2011) Krzysztof Wodiczko. Art of the public domain, Sopot-Warszawa: Państwowa Galeria Sztuki w Sopocie, Fundacja Profile w Warszawie.

Czubak Bożena (2015), Krzysztof Wodiczko. Na rzecz domeny publicznej, ed. B. Czubak, Łódź: Muzeum Sztuki w Łodzi.

34 B. Czubak, Projekcja weteranów wojennych, Warszawa, http://fundacjaprofile.pl/tree.php?i$\mathrm{d}=862(17.06 .2021)$

35 Ibidem.

36 H. Lefebvre, The Production of Space, Blackwells, Oxford 1991.

37 N. Kaye, Site-Specific Art. Performance, Place and Documentation, Routledge, London 2000, p. 37.

38 K. Wodiczko, Monument, Parrhesia, Projection, [in:] Krzysztof Wodiczko..., op. cit. p. 165.

39 The problem was tackled by Delfina Jałowik in the article: Participative Art: Delegated Performance versus Communal Engaged Performance Using the Example of Artistic Activities by Krzysztof Wodiczko and Pawet Althamer, "Art Inquiry. Recherches sur les arts" 2018, vol. XX (XXIX), pp. 159-171. 
Czubak Bożena, Projekcja weteranów wojennych, Warszawa, http://fundacjaprofile.pl/tree.php?i$\mathrm{d}=862(17.06 .2021)$

http://artmuseum.pl/pl/filmoteka/praca/wodiczko-krzysztof-projekcja-weteranow-wojennychwarszawa (17.06.2021)

Kaye Nick (2000) Site-Specyfic Art. Performance, Place and Documentation, London: Routledge.

Jałowik Delfina (2018) Participative Art: Delegated Performance versus Communal Engaged Performance Using the Example of Artistic Activities by Krzysztof Wodiczko and Pawet Althamer, „Art Inquiry. Recherches sur les arts” vol. XX (XXIX), pp. 159-171.

Kobylt Joanna, Radykalna utopia - o krytyce spotecznej Krzysztofa Wodiczki, https://archiwumobieg.u-jazdowski.pl/recenzje/9987 (17.06.2021)

Lefebvre Henri (1991) The Production of Space, Oxford: Blackwells.

Potocka Maria Anna ed. (2002) Publiczna przestrzeń dla sztuki?, Kraków: Bunkier Sztuki.

Smolak Anna, Gadomska Małgorzata, Doliński Dariusz eds. (2005) Wodiczko. Projekcje publiczne 1996-2004, Kraków: Bunkier Sztuki.

Szabłowski Stach, Dobry artysta, "dwutygodnik.com" 2015, Vol. 166, No. 8, www.dutygodnik. com/artykul/6064-dobry-artysta.html (07.11.2020)

Wodiczko Krzysztof (1999) Critical Vehicles. Writings, Projects, Interviews, Cambridge - Massachusetts - London: The MIT Press.

\section{DYSKURS Z ARCHITEKTURA W TWÓRCZOŚCI KRZYSZTOFA WODICZKI (streszczenie)}

Twórczość Krzysztofa Wodiczki podzielić można na trzy grupy. Pierwszą stanowią różnego rodzaju pojazdy. Drugą grupą prac Wodiczki, jak pisał Stach Szabłowski, są "projekty technologicznych protez dla osób społecznie <<upośledzonych〉> - uchodźców, emigrantów, bezdomnych"40. Trzecia grupa - najbardziej znana to projekcje publiczne, polegające na rzutowaniu na różne słynne budowle obrazów (początkowo statycznych, a od 1996 roku ruchomych i połączonych z dźwiękiem), które miały na celu zwrócenie uwagi na ważne dla mieszkańców danego miejsca kwestie kulturowe, społeczne i polityczne.

W artykule autorka koncentruje się na omówieniu ostatniej z wymienionych grup, wskazując że projekcje artysty z jednej strony odnoszą się do realnych, bieżących problemów trapiących

40 S. Szabłowski, Dobry artysta, „dwutygodnik.com” 2015, Vol. 166, No. 8, www.dutygodnik. com/artykul/6064-dobry-artysta.html (07.11.2020) 
mieszkańców danego miejsca, z drugiej poprzez tworzenie ich z myślą o konkretnych budowlach wchodzą w dyskurs z zastaną architekturą, która w powszechnym odczuciu ma charakter uniwersalny, ponadczasowy, daleki od tego, co dzieje się aktualnie.

Słowa kluczowe: dyskurs, architektura, projekcje publiczne, Krzysztof Wodiczko

Paulina Sztabińska-Kałowska - PhD, associate professor in the Department of Art History, University of Łódź. Winner of the Jan Józef Lipski award for best MA thesis (2003) and the Szczęsny Dettloff award for best doctoral dissertation (2008). Author of the books: Geometria a natura. Polska sztuka abstrakcyjna $w$ drugiej polowie XX wieku [Geometry and nature. Polish abstract art in the second half of the twentieth century], Warszawa 2010 and Sztuka geometryczna a postmodernizm [Geometric Art and Postmodernism], Warszawa 2011. Co-author and co-editor of the book The proper names in the art of Łódź. Contemporary painting, graphic arts, sculpture and intermedia, Łódź 2008. Editorial associate of the journal Art Inquiry. Recherches sur les arts. Her research interests focus on the twentieth century art and art theory. 